\title{
A Rhodococcus erythropolis NI86/21 talajbaktérium mezőgazdasággal kapcsolatos kutatási eredményei 1986-tól napjainkig
}

\section{Bevezetés}

Az egyik leginkább kutatott rodokokkusz törzs a $R$. erythropolis NI86/21, melyet 1986-ban izoláltunk kukoricanövény gyökeréről a Gödöllői Agrártudományi Egyetemen (ma Szent István Egyetem) müködő „Mikrobiológiai Mühely” keretei között. E törzs különlegessége, hogy egyedüli szén- és nitrogénforrásként tiokarbamát herbicideket (EPTC, butilát és vernolát) képes hasznosítani (NAGY et al., 1987a). Tenyészedénykísérletekben megfigyeltük, hogy ezeknek a pre-emergens herbicideknek a kukorica tesztnövényre kifejtett fitotoxikus hatását a baktérium az alkalmazott sejtszámtól függöen mérsékli, illetve teljesen kivédi úgy, hogy a növényvédő szer gyomirtó hatása közben megmarad. A későbbiekben kisparcellás szántóföldi kísérletek is bizonyították, hogy a baktérium mezőgazdasági méretekben is képes megvédeni a kukoricát e három tiokarbamát fitotoxikus hatásától (NAGY et al., 1987b). Az eljárásnak, illetve a baktériumnak a „bioantidótum” elnevezést adtuk.

A további munkák során kutatásaink célkeresztjébe a herbicidbontásért felelős gének izolálása és azonosítása került, de emellett alapvető fontosságú genetikai eszközöket, DNS-, RNS- és fehérjefeltárási módszereket is kidolgoztunk. Az eredeti cél elérése mellett egy E. coli - Rhodococcus klónozó vektort, és egy Rhodococcus mutációs rendszert is kifejlesztettünk, melyet MITANI és munkatársai (2006) fejlesztettek tovább. Azt is megállapítottuk, hogy a törzs nemcsak tiokarbamátokon, hanem triazin vegyületeken is képes szaporodni, és hogy a triazinok bontásáért is (csakúgy, mint a tiokarbamátok lebontásáért) a CYP116 enzim és a hozzá tartozó redox rendszer a felelös (NAGY et al., 1995a,b). A herbicidbontó gének szekvenálása során az első eubakteriális proteaszóma géneket is megtaláltuk a thcB gén szomszédságában. Ez irányú vizsgálataink a Rhodococcus proteaszóma alegységszerkezetének, a negyedleges szerkezet kialakulásának, illetve az alegységszerkezet kialakulásáért felelős propeptid szerkezetének és hatásmechanizmusának a kiderítésére irányultak (TAMURA et al., 1995; ZUHL et al., 1997; KWON et al., 2004).

Összefoglaló munkámat Kecskés Mihály 75. születésnapja és a Rhodococcus erythropolis NI86/21 törzs izolálásának 20. évfordulója alkalmából állítottam össze azzal a kettős céllal, hogy egyrészt megemlékezzek a „Gödöllői Mikrobiológiai Mühely" kutatási eredményeiről, másrészt, hogy a törzsnek és génjeinek a gyakorlati alkalmazási lehetőségeire rávilágítsak. 


\section{A Rhodococcus erythropolis NI86/21 törzs bioantidótum hatása}

A tiokarbamát herbicideket preemergens gyomirtó szerként használják főleg egyszikü gyomok ellen (WARE, 1994). E herbicidcsalád magában foglalja többek között az EPTC (S-etil-dipropil-tiokarbamát), butilát (S-etil-N,N-diizobutil-tiokarbamát), vernolát (S-n-propil-N,N-di-n-propil-tiokarbamát), cikloát (S-etil-N-etil-N-ciklohexil-tiokarbamát), diallát [S-(2,3-diklór-allil)-diizopropil-tiokarbamát], pebulát (S-propil-butil-etiltiokarbamát) stb. vegyületeket. Az EPTC-t egyéves és évelö egyszikü gyomok ellen használják különböző növénykultúrák, így a kukorica, a gyapot és a bab vegyszeres gyomirtására. Az EPTC és a butilát alkalmazási körének kiszélesítésében fontos lépés volt a diklormid (R-25788: N,N-diallil-2,2-dikloro-acetamid) vegyülettel történő együttes alkalmazás, amely mint antidótum képes megvédeni a kukoricanövényt e tiokarbamátok fitotoxikus hatásától (PHILLIPS \& MCDOUGALL, 1993).

Az 1970-es évek végétől vált közismertté, hogy bizonyos peszticidek (melyek föleg a karbamátok, tiokarbamátok, fenoxi-ecetsavak, szerves foszfátok családjába tartoznak) hatástartama lerövidül azokban a talajokban, melyeknek kezelésére e vegyületeket több egymást követő évben használták. Az ilyen talajokat adaptált, vagy a vegyszeres gyomirtás szempontjából problematikus talajnak nevezték el (RAHMAN et al., 1979). A vizsgálatok bebizonyították, hogy a jelenség oka a mikroorganizmusok adaptációs képessége (GRAY \& WEIERICH, 1968), mely alkalmassá teszi öket arra, hogy a környezetböl érkező biokémiai és élettani kihívásoknak megfeleljenek, és akár az új, szintetikus peszticideket is szaporodásukhoz egyedüli szén- (és esetenként nitrogén-) forrásként hasznosítsák (BIRÓ \& KECSKÉS, 1984). A tiokarbamát-családban a felgyorsult lebontás jelenséget az EPTC, vernolát és a butilát esetében fígyelték meg, de a cikloáttal kapcsolatban ilyen tapasztalatok nincsenek. Az ,adaptált talaj” jelenség, a kukorica vetésterületén bármely talajtípusban előfordulhat, ha a talaj mikrobiológiai aktivitása kellőképpen intenzív (OBRIGAWITCH et al., 1982; KÁTAI, 1997).

Tenyészedény-kísérletek során észleltük, hogy az EPTC-vel elökezelt talaj jól antidotálja az EPTC, butilát és vernolát fitotoxikus tüneteit, az ilyen talajokban a kukoricanövény kevésbé károsodott. A kísérleteket négy tiokarbamátra terjesztettük ki, az EPTC-vel, butiláttal, vernoláttal és cikloáttal előkezelt talajokban a vegyszeres kezeléstől számított két hónap eltelte után kukorica tesztnövény alkalmazásával tanulmányoztuk a tiokarbamátok lebomlási ütemét és kereszt antidotálási viszonyait is (1. táblázat a) és b) sorok), amelyek a következők szerint alakultak:

- az EPTC-vel előkezelt talaj az EPTC, a butilát és a vernolát fitotoxikus tüneteit $60-70 \%$-ban,

- a butiláttal előkezelt talaj az EPTC, a butilát és a vernolát fitotoxikus tüneteit 66$88 \%$-ban,

- a vernoláttal előkezelt talaj az EPTC, a butilát és a vernolát fitotoxikus tüneteit 78-84\%-ban,

- a cikloáttal előkezelt talaj csak a cikloát fitotoxikus tüneteit enyhítette mintegy $50 \%$-ban (NAGY, 1989).

A talajban kialakuló antidótum tulajdonságot vizsgálva megállapítottuk, hogy az EPTC-vel kezelt talajokban mind a $17-18{ }^{\circ} \mathrm{C}$-on, mind a $28{ }^{\circ} \mathrm{C}$-on inkubált kezelésekben kialakul az antidótum hatás, ami azonban autoklávval, vagy gamma-besugárzással történő sterilezés után eltünik a talajból. Ez a tény tehát egyértelműen azt bizonyította, hogy a talaj antidótum hatásáért a talaj mikrobiális aktivitása a felelős (NAGY, 1989). 
1. táblázat

A tiokarbamátok $\left(61 \cdot h^{-1}\right)$ mikrobiális lebontásának (a) és a kukoricanövény biológiai antidotálhatóságának (b) a kapcsolatrendszere herbicidekkel kétszer előkezelt talajokban $(2 \times)$, valamint a $R$. erythropolis NI86/21 törzs tiokarbamát-bontó (c) és kukorica antidotáló (d) képessége $9,3 \times 10^{6} \mathrm{sejt} \cdot \mathrm{g}^{-1}$ talaj mennyiségben (NAGY, 1989)

\begin{tabular}{|c|c|c|c|c|}
\hline \multirow{2}{*}{ Biológiai jelenség } & \multicolumn{4}{|c|}{ Vizsgált herbicid $\left(61 \cdot \mathrm{ha}^{-1}\right)$} \\
\hline & EPTC & Butilát & Vernolát & Cikloát \\
\hline a) Herbicidbontás talajban & & & & \\
\hline ЕРТC $2 \times$ & + & + & + & - \\
\hline Butilát 2x & + & + & - & - \\
\hline Vernolát $2 \times$ & + & + & + & - \\
\hline Cikloát $2 \times$ & - & - & - & + \\
\hline b) Talaj antidótum-hatás & & & & \\
\hline EPTC $2 \times$ & + & + & + & - \\
\hline Butilát 2× & + & + & + & - \\
\hline Vernolát $2 \times$ & + & + & + & - \\
\hline Cikloát $2 \times$ & - & - & - & - \\
\hline c) A R. erythropolis & & & & \\
\hline $\begin{array}{l}\text { NI86/21 törzs } \\
\text { tiokarbamát bontása }\end{array}$ & + & + & + & - \\
\hline d) A R. erythropolis & & & & \\
\hline $\begin{array}{l}\text { NI86/21 törzs kukorica } \\
\text { antidotáló képessége }\end{array}$ & + & + & + & - \\
\hline
\end{tabular}

Az ilyen „bioantidótum” jelenséget az $R$. erythropolis NI86/21 törzzsel modellezni tudtuk: a talajba oltott törzs az EPTC és a butilát fitotoxikus tüneteit $3,3 \times 10^{4} \mathrm{sejt} \cdot \mathrm{g}^{-1}$, a vernolát fitotoxikus tüneteit $3,3-9,3 \times 10^{6}$ sejt $\mathrm{g}^{-1}$ mennyiségben kivédte, a cikloát fitotoxicitását viszont nem tudta mérsékelni (1. táblázat c) és d) sorok).

A $R$. erythropolis NI86/21 törzs a fentiek értelmében alkalmas arra, hogy a mezőgazdasági gyakorlatban antidótum-hatású vegyületek helyett használjuk az EPTC, a butilát és a vernolát herbicidekkel kombinációban, és ezzel csökkenthessük a környezetünkbe juttatott kemikáliák mennyiségét. Az eljárás másik fontos aspektusa az, hogy amíg a kémiai antidotálás során az antidótum vegyület a herbiciddel együtt a növénybe kerül és ott fejti ki hatását, addig a bioantidótum eljárásnál a baktérium-kezeléssel mintegy védőpajzsot vonunk a növény gyökerei köré, amely feltételezhetően meggátolja, hogy az aktív növényvédőszer-molekula a növénybe kerüljön. Az ilyen irányú kutatások fejlesztése ezért nemcsak a bioantidótum eljárások, hanem a fitoremediációs módszerek alkalmazását is elősegíthetné a xenobiotikumok (KECSKÉS, 1976) által szennyezett területeken.

\section{A $R$. erythropolis NI86/21 törzs tiokarbamát metabolizmusa}

A talajba juttatott tiokarbamátok lebontását mikrobák katalizálják, és ezek közül is néhány Rhodococcus fajról írták le azt a képességet, hogy a tiokarbamátokat egyedüli szén- és nitrogénforrásként tudják hasznosítani. A R. erythropolis NI86/21 törzsön kívül a Rhodococcus sp. TE1 (BEHKI \& KHAN, 1990) és a Rhodococcus sp. JE törzsek EPTC 
hasznosítását tanulmányozták részleteiben (ANKUMAH et al., 1995). A JE1 törzsben az EPTC lebontása az N,N-dialkil gyök $\alpha$-propil szénatomjának hidroxilezésével kezdődik, majd a következő lépésben az instabil $\alpha$-hidroxipropil EPTC propionaldehidre és Ndepropil-EPTC-re bomlik. Ezek mellett még az EPTC-szulfoxid volt nyomokban kimutatható. A TE1 törzs viszont az EPTC bontása folyamán dipropilamint produkál, ami egy másfajta EPTC metabolizmust tükröz (BEHKI \& KHAN, 1990).

Az NI86/21 törzs a tiokarbamátok metabolizmusa során N-dealkilált és hidroxilált metabolitokat is termel. A GC-MS vizsgálataink N-depropil EPTC-t és $\beta$-hidroxipropil vernolátot mutattak ki (NAGY et al., 1995b,c) mint fó bomlástermékeket, de nyomokban EPTC-szulfoxid, és dipropilamin is megtalálható volt. Ezek az eredmények azt tükrözik, hogy az NI86/21 törzsben mind a két - rodokokkuszokban megtalálható - tiokarbamát anyagcsere folyamat müködik.

\section{A $R$. erythropolis NI86/21 törzs tiokarbamát-bontó enzimei}

Az EPTC bomlástermékeinek vizsgálata után az EPTC lebontását katalizáló géntermékek azonosítását tekintettük alapvető feladatunknak. Ebben a munkánkban egy ma már rutinszerüen használt módszert, a proteom analízist választottuk első lépésnek. Az alapsóoldatban EPTC-én és ecetsavon szaporodó $R$. erythropolis NI86/21 sejtekböl kivont fehérjéket kétdimenziós poliakrilamid-gélelektroforézis technikával választottuk szét és azt figyeltük meg, hogy az ecetsavon szaporodó sejtekhez képest mely proteinek szintje emelkedett meg az EPTC-én tenyésztett sejtekben. E módszerrel négy proteint sikerült kimutatni, melyek molekulasúlya 56, 51, 49 es $30 \mathrm{kDa}$ volt. Ezek közül kettő (56 és $49 \mathrm{kDa}$ ) az EPTC-én és butiláton növekvő sejt legnagyobb mennyiségben előforduló fehérjéje volt (1B. és 1C. ábra). Mind a négy fehérjét izoláltuk és N-terminális aminosav sorrendjüket Edmann-degradációval meghatároztuk (NAGY et al., 1995b).

A kapott eredmények alapján degenerált oligomereket szintetizáltattunk. Ezeket $\mathrm{P}^{34}$ gyel, vagy digoxigeninnel jelöltük és Southern-hibridizációs kísérletekben a különböző restrikciós endonukleázokkal emésztett és agaróz gélben elválasztott $R$. erythropolis NI86/21 DNS-hez hibridizáltuk. Ezek alapján kiválasztottuk a megfelelő nagyságú (4 $10 \mathrm{~kb})$ DNS szálakat, melyek az EPTC-bontásért felelös géneket is tartalmazták, és $E$. coli-ban - pUC18 vektor segítségével - klónoztuk őket. E mini génkönyvtárból egy második hibridizációval kiválasztottuk a pozitív klónokat, majd meghatároztuk az inszertek DNS szekvenciáját. A nagyobb méretü DNS darabokat (14-23 kb) LambdaT4 fágban klónoztuk, és fág hibridizációs kísérletekben kiválasztottuk a pozitív klónokat. Ezekből alkönyvtárat készítettünk pUC18 plazmidban és meghatároztuk a DNS szekvenciákat. Ezeket a BLAST program segitségével azonosítottuk. Azonosítottnak azokat a géneket/szekvenciákat tekintettük, amelyeknél a transzláció során kapott aminosav szekvencia teljesen megegyezett az Edmann-degradációval kapott N-terminális aminosav sorrenddel.

$\mathrm{Az} 56 \mathrm{kDa}$ nagyságu fehérje $\mathrm{NAD}^{+}$-függő aldehid dehidrogenáznak bizonyult, $\mathrm{s}$ számított molekulatömege 54,863 kDa-nak adódott. A legnagyobb aminosav-szekvencia hasonlóságot az Alcaligenes euthrophus (PRIEFERT et al., 1992) és a Vibrio cholerae (PARSOT \& MEKALANOS, 1991) aldehid dehidrogenázaival mutatta, az azonosság 73, ill. 60\% volt. Ezek az enzimek az acetaldehidet alakítják át ecetsavvá. Az $A$. euthrophus enzim az acetoin etilalkohollá történő átalakításában játszik szerepet, míg a 

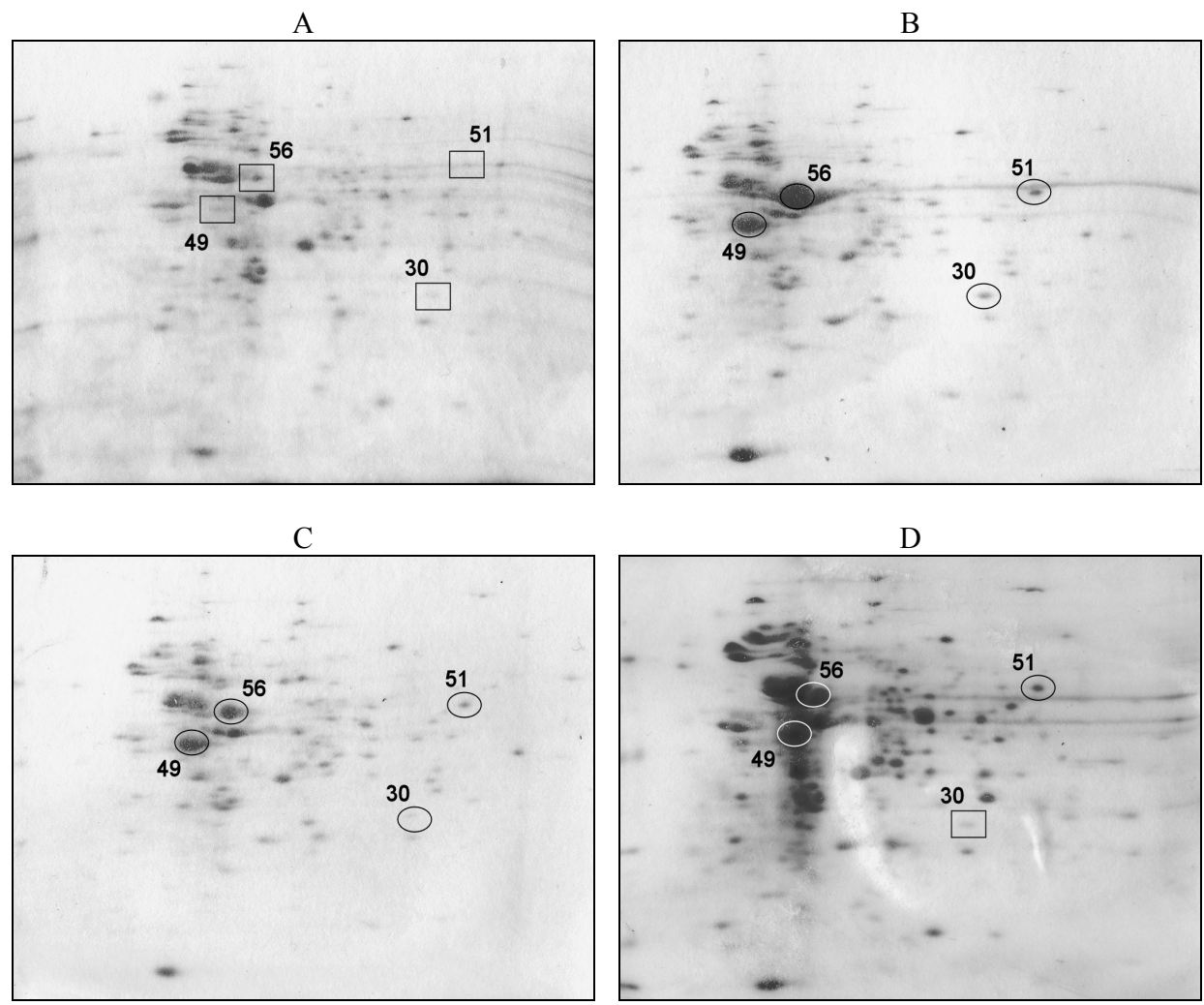

1. ábra

A különböző szénforrásokon (A. ecetsav, B. EPTC, C. butilát, D. atrazin) tenyésztett $R$. erythropolis NI86/21 törzs kétdimenziós poliakrilamid elektroforetogramjának (2D-PAGE) fehérje analizise. Az $56 \mathrm{kD}$ (ThcA), $51 \mathrm{kD}$ (ThcF), $49 \mathrm{kD}$ (ThcB) és $30 \mathrm{kD}$ (ThcE) fehérjék jelenlétét ovális, a hiányukat négyszög jelzi. A tiokarbamát és atrazin herbicideken tenyésztett sejtekben az $56 \mathrm{kD}$ és $49 \mathrm{kD}$ fehérjék domináns jellege feltünő

$V$. cholerae metabolikus funkciójáról keveset tudunk. A ThcA enzim hosszú szénláncú alifás aldehideken a legaktívabb (a formaldehidet nem képes konvertálni), és enzim specifitásában az Amycolatopsis methanolica aldehid dehidrogenázához hasonlít legjobban (NAGY et al., 1995b).

Azzal is foglalkoztunk, hogy a thcA gén szomszédságában vannak-e EPTC által indukálható fehérje szekvenciák. Mivel az azonosított proteinek szekvenciája közül egyiket sem találtuk meg a thcA gén közelében, vizsgálatainkat más klónok analízisére irányítottuk. Ezek közül elsőként a LambdaFAJ2028 jelủ fág szekvenciáját határoztuk meg. Ezen a klónon be tudtuk azonosítani a 49 kDa nagyságú fehérjét kódoló gént, melynek analízise egy új típusú citokróm P450-t (ThcB) mutatott ki. A bakterialis CYP450 enzimek szekvenciájának összehasonlító analízise azt is bizonyította, hogy enzimünk az új CYP116 család első tagja (NAGY et al., 1995b).

A különböző rodokokkusz fajokból származó DNS-DNS hibridizációs kísérleteink kimutatták, hogy a thcA gén mindegyik vizsgált rodokokkusz törzsben, a thcB gén vi- 
szont csak az NI86/21 törzsben van jelen. Ezért feltételeztük, hogy a ThcA enzim az EPTC bontás közbenső - a ThcB által indukált - termékeit bontja tovább. A ThcB enzim lényegi szerepét az EPTC lebontásban úgy igazoltuk, hogy az EPTC lebontásában valószínüsíthetően szerepet játszó génekkel transzformáltuk az EPTC-t nem bontó és bioantidótum hatással nem rendelkező $R$. erythropolis SQ1 törzset. Az SQ1 transzformánsok bioantidótum hatását EPTC-vel kezelt talajba vetett kukoricanövényen tanulmányoztuk. Megállapítottuk, hogy csak az a klón, mely a teljes thcB operont $(t h c B)$, rhodocoxin $(t h c C)$ és rhodocoxin reduktázt $(t h c D)$ tartalmazta (pFAJ2309) volt képes megvédeni a kukoricanövényeket az EPTC fitotoxikus hatásától (2. ábra). Meg kell azonban jegyeznünk, hogy e törzs EPTC $\left(100 \mathrm{mg} \cdot \mathrm{l}^{-1}\right)$ bontása igen lassú (12 nap) volt az NI86/21 törzshöz (2 nap) viszonyítva. Ez a lassú folyamat az alacsony ThcB szintnek $\left(9,7 \mathrm{pmol} \cdot \mathrm{mg}^{-1}\right.$ proteintartalom) köszönhetö, ami 18-ad része volt az NI86/21ben találhatónak.

Azok a transzformánsok, melyek nem tartalmazták a $t h c B$ gént hatástalanok voltak, csakúgy mint a $t h c B$ gén, ha a thc $C$ és $t h c D$ gének nem voltak a plazmidon. Ez azt jelzi, hogy a thc $C$ és $t h c D$ gének lényegi szerepet játszanak egy jól müködö elektrontranszferlánc kialakításában, a redox rendszer regenerálódását biztosítva. Egy másik kísérletben az EPTC mínusz NI86/21 mutánsba (FAJ2027) csak a thcB gént tartalmazó plazmidot vittük be (pFAJ2350), és ez egymagában visszaállította az EPTC bontó hatást (2. ábra). Ez arra bizonyíték, hogy a mutáció e törzs esetében a thcB génben történt, és a rhodocoxin-rhodocoxin reduktáz rendszer érintetlen maradt.

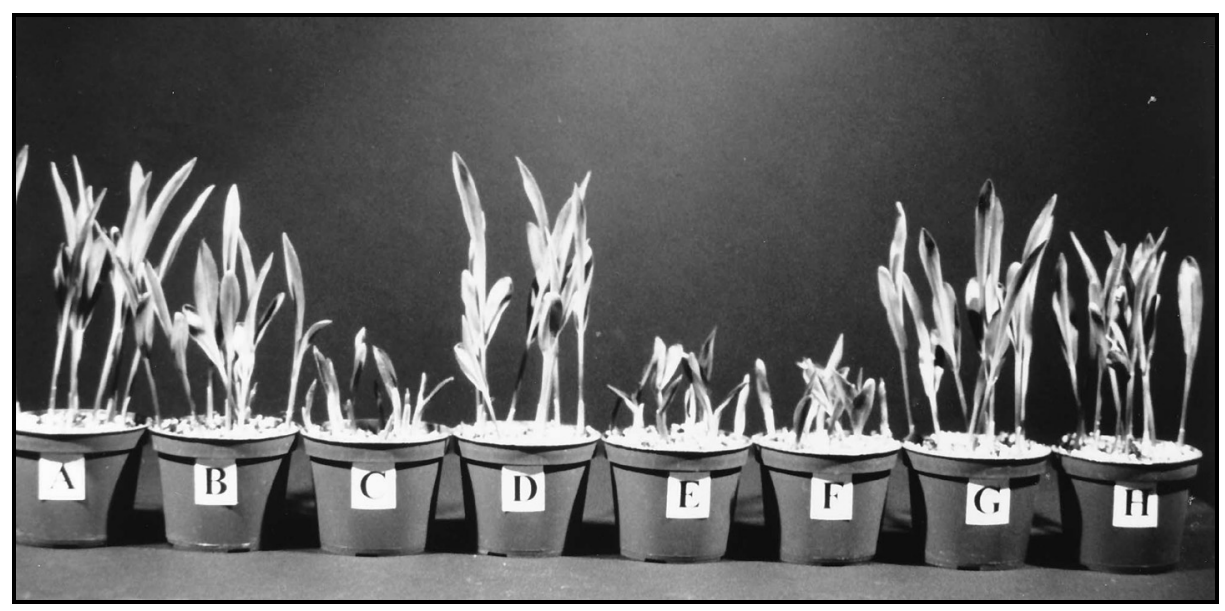

2. ábra

Különbözö Rhodococcus törzsek bioantidótum hatása EPTC-vel kezelt kukoricanövényeken A kezelések sorrendje: A. Kezeletlen kontroll. B. Alirox 80 EC (EPTC 72\% + 8\% AD-67 kémiai antidótum). C. EPTC antidótum nélkül (Witox 72 EC). D. R. erythropolis NI86/21 oltás. E. $R$. erythropolis SQ1. F. EPTC-negatív mutáns NI86/21 törzs (FAJ2027). G. A pFAJ2309 plazmiddal transzformált $R$. erythropolis SQ1. H. A pFAJ2350 plazmiddal transzformált FAJ2027 törzs. Az eredményeket az EPTC jelenlétében növekvő kukoricanövényen (C), a vetéstől számított tizedik napon értékeltük (NAGY et al., 1995b). A plazmidok a következő géneket hordozták: pFAJ2350 (thcB), pFAJ2309 (thcBCD) 
Elmondhatjuk tehát, hogy a $R$. erythropolis NI86/21 I. típusba tartozó CYP450 enzim a hozzá tartozó redox rendszerrel együtt egy működő elektrontranszfer-láncot alkot, mely az EPTC lebontását specifikusan katalizálja. Az általanos sémát (NADH-FAD reduktáz-Fe/S redoxin-P450-szubsztrát) követve, esetünkben az elektronok a NADHThcD-ThcC-ThcB-EPTC irányba vándorolnak. Az enzimhasítás következményeként depropil-EPTC és propionaldehid keletkezik. Ez utóbbit az aldehid dehidrogenáz enzim (ThcA) alakítja tovább a megfelelő savvá, mely aztán belép a központi anyagcsereútba. Nagy valószínüséggel a depropil-EPTC is tovább bomlik, minthogy az NI86/21 törzs nitrogénmentes táptalajon is képes szaporodni EPTC-n, ami a vegyület mineralizálódását jelenti.

A harmadik EPTC által indukált fehérje $(30 \mathrm{kD})$, melyet proteom analízissel és az azt követő szekvencia meghatározással azonosítottunk, egy haloperoxidáznak bizonyult, és 71\% aminosav homológiát mutatott a Pseudomonas pyrrocinia kloroperoxidázával (WolfFrAMM et al., 1993) és a ThcF triviális nevet kapta. A poliklonális antitest - melyet $P$. pyrrocinia kloroperoxidáz ellen termeltettek - keresztreakciót adott a ThcFfel, ezzel is alátámasztva a hasonlóságot. Későbbi kutatások kimutatták, hogy a ThcF a többi kofaktor nélküli haloperoxidázzal szemben indukálható, és az eredeti hipotézis, hogy a bakteriális haloperoxidázok halogénezett vegyületek szintézisében játszanak szerepet megváltozott, így a haloperoxidáz elnevezés nem helytálló. Katalitikus aktivitásuk az „SDH” katalitikus triádon alapszik, mely a szerin-hidrolázokra jellemző, ezért e családba történő besorolásuk megalapozott. A szerin-hidrolázok családjába észterázok, proteázok, lipázok és hidrolázok tartoznak, és jellemző rájuk az $\alpha / \beta$ hidroláz szerkezet. A ThcF génterméknek mind hidroláz, mind észteráz aktivitását kimutattuk, mely aktivitásokat hidroláz inhibitorokkal sikerült blokkolni, ami az „SDH” katalitikus triád aktivitására utal. E tulajdonságok alapján a ThcF-t az első hidroláz/észteráz aktivitással rendelkező haloperoxidáznak tekinthetjük a mikolinsavat termelő aktinomicétáknál (DESCHRIJVER et al., 1997).

A rekombináns ThcF enzim aktivitását tiokarbamátokon is megvizsgálták és megállapították, hogy a ThcF $\mathrm{H}_{2} \mathrm{O}_{2}$ - és acetátionok jelenlétében a tiokarbamátokat oxidálják és tiokarbamát-szulfoxidokat termelnek (DESCHRIJVER et al., 1997; DE MOT et al., 2003). Más szerin-hidrolázok esetében is leírták, hogy természetes hidrolitikus hatásuk mellett képesek hidrogén-peroxidot használni perhidrolitikus reakciók kivitelezésére. Valószínü, hogy a ThcF is hasonló reakciót katalizál tiokarbamátok esetében, bár azt még nem tisztáztuk, hogy az NI86/21 sejtekben a ThcF vagy a ThcB felelős az EPTCszulfoxid szintetizálásáért, minthogy elvileg mindkét enzim képes a reakció kivitelezésére.

A negyedik tiokarbamátokkal indukálható fehérje génjét is klónoztuk és jellemeztük, és a fehérje a ThcE jelzést kapta. A rekombináns fehérje inaktiv, szerkezet nélküli formában termelődött, ezért enzimaktivitását nem sikerült meghatározni. Megállapítottuk viszont, hogy expressziója a tiokarbamátokon kívül atrazinnal, etanollal, propanollal, propionaldehiddel és etanolaminnal is indukálható az NI86/21 sejtekben. Aminosav szekvenciája nagy hasonlóságot mutat az Amycolatopsis methanolica homodekamer negyedleges szerkezetü, N,N'-dimetil-4-nitrozoanilin-függő alkohol reduktázával (MNO) (NAGY et al., 1995c). Az enzim funkciójáról pontos adatokkal nem szolgálhatunk, azt viszont joggal feltételezhetjük, hogy nem az EPTC-lebontás első lépéseit katalizálja, hanem valamely egyszerübb bomlástermékét, mivel propionaldehiddel (az EPTC egyik bomlástermékével) is indukálható az expressziója. 
A ThcF fehérjének egy más jellegü, de a mezőgazdasággal összefüggő szerepéről is be kell számolnunk. Először a Pseudomonas pyrrocinia kloroperoxidázáról (CPO-P) mutatták ki, hogy $\mathrm{H}_{2} \mathrm{O}_{2}$ felhasználásával az alkil savakat a megfelelö peroxidokká oxidálja. E peroxidok potenciális gombaölö szerek, mint azt a perecetsav esetében sikerült bizonyítani. Azt, hogy az enzim meg tudja-e védeni a növényt gombapatogénekkel szemben úgy vizsgálták, hogy a cpo-P génnel (JACKS et al., 2000) dohánynövényt transzformáltak. Eredményül azt kapták, hogy a genetikailag módosított dohány rezisztens lett az Aspergillus flavus ellen, és ez a hatás nem az enzim peroxidáz, hanem hidroláz aktivitásával volt összefüggésben. A $R$. erythropolis NI86/21 thcF génjének hatását (SELS, 2003) és (VELGHE, 2004) vizsgálták Arabidopsis thaliana növényben. A növény sikeres transzformálása után megállapították, hogy a növény levelének kivonata eröteljesebb gombaölö hatást mutat Fusarium culmorum ellen, mint a kontrollnövény. Azt is megállapították, hogy e hatásért nem valamilyen fehérje, hanem egy máig azonosítatlan vegyület a felelős. Ennek a vegyületnek az azonosítása és további vizsgálata szükséges ahhoz, hogy stabilitását, valamint szintetikus formájának gyakorlati alkalmazási lehetőségeit megállapíthassuk.

\section{A $R$. erythropolis NI86/21 törzs atrazin metabolizmusa}

Munkánk során tanulmányoztuk azt is, hogy a tiokarbamát-bontó gének/enzimek szerepet játszanak-e más herbicidek lebontásaban is? E kísérletekben az atrazinra összpontosítottunk, mivel a Rhodococcus sp. TE1 törzsről leírták, hogy nemcsak az EPTC-t, hanem az atrazint is képes N-dealkilezni (BEHKI et al., 1993). Az NI86/21 törzs atrazin metabolizmusát különböző feltételek mellett vizsgáltuk. Alapsóoldatba $55 \mu \mathrm{g} \cdot \mathrm{ml}^{-1}$ atrazint oldottunk be és $30{ }^{\circ} \mathrm{C}$-on, rázatott kultúrákban inkubáltuk a mikrobát. $\mathrm{Az}$ atrazinlebontást gázkromatográfiás szermaradvány vizsgálattal, 24 órás időközönként, 96 óráig követtük. Néhány kísérletben az alapsóoldatból az ammónium-nitrát N-forrást kihagytuk, vagy extra szénforrásként $1 \mathrm{~g} \cdot \mathrm{liter}^{-1}$ fruktózt adtunk. A legtöbb kísérletben nagy sejtkoncentrációt ( $20 \mathrm{~g} \cdot$ liter $^{-1}$ ) alkalmaztunk, de megvizsgáltuk 30-szoros sejtszám hígítású kultúrák $\left(\mathrm{OD}_{600} 0.19\right)$ atrazin lebontását is. A kontrollkísérletekben az atrazinszint nem változott, ezzel szemben az NI86/21 törzs az atrazint 96 óra alatt eltüntette a tápoldatból. A nitrogénforrás megvonása felgyorsította a vegyület lebontását (48 h), de még ennél is intenzívebb hatást mértünk, ha extra szénforrást juttattunk a tápoldatba. Ebben az esetben a $0,19 \mathrm{OD}_{600}$ sejtkoncentrációjú kultúra is 96 óra alatt lebontotta az atrazint (NAGY et al., 1995a) (2. táblázat I. sor)

Megállapítást nyert az is, hogy három bomlástermék a de-izopropilatrazin, a deetilatrazin, és a hidroxi-izopropilatrazin halmozódik fel a táptalajban. Ezek a végtermékek tovább nem voltak bonthatók az NI86/21 törzs által, deklórozott termék nem keletkezett és a triazin gyürü hasítása sem történt meg. Bár az NI86/21 törzs nem tudja az atrazint teljes mértékben lebontani, a végtermékek szubsztrátként szolgálnak más mikrobák számára, melyek teljessé teszik a lebontást. A R. erythropolis NI86/21 atrazin metabolizmusának folyamatát más mikrobiális atrazinlebontási utakkal együtt a http://umbbd.ahc.umn.edu/atr/atr_map.html web oldalon lehet megtekinteni. 


\section{2. táblázat}

A R. erythropolis NI86/21 törzs atrazinbontása és a tiokarbamát-bontó génekkel transzformált FAJ2027 (mutáns NI86/21) és a R. erythropolis SQ1 törzsek atrazinbontása alapsóoldatban

(NAGY et al., 1995a)

\begin{tabular}{|l|l|c|c|c|c|}
\hline \multirow{2}{*}{ Törzs } & \multirow{2}{*}{ Tápoldat $^{\mathrm{a}}$} & \multicolumn{4}{|c|}{ Atrazinmaradvány (\%) } \\
\cline { 3 - 6 } & & 24 óra & 48 óra & 72 óra függvényében: & 96 óra \\
\hline \multirow{2}{*}{ I. NI86/21 } & BSM & 48,0 & 18,0 & 11,0 & 10,0 \\
& BSM (-N) & 60,0 & 23,0 & 4,0 & 0,0 \\
& BSM (+C) & 11,0 & 0,0 & ND $^{c}$ & ND \\
& BSM (+C) & 43,0 & 14,0 & ND & 10 \\
II. FAJ2027(pFAJ2350) & BSM & ND & 63,0 & ND & 40,0 \\
III.FAJ2027(pFAJ2308) & BSM & ND & 20,0 & ND & 7,0 \\
& BSM (+C) & \\
IV. SQ1(pFAJ2309) & BSM (+C) & 10,0 & 10,0 & 0,0 & ND \\
& & 100 & 86,0 & 69,0 & 64,0 \\
\hline
\end{tabular}

Megjegyzés: ${ }^{a}$ BSM, basal salt medium (alapsóoldat); BSM (-N): BSM ammónium-nitrát nélkül; BSM $(+\mathrm{C})$ : BSM $+1 \mathrm{~g} \cdot$ liter $^{-1}$ fruktóz; ${ }^{b}$ Az értékek három párhuzamos minta átlagai. A kezdeti atrazinkoncentració $230 \mu \mathrm{mol}$ volt. ${ }^{c} \mathrm{ND}$, nem meghatározott érték. ${ }^{d} \mathrm{Az}$ eredeti sejtszámot $(20$ $\mathrm{g} \cdot$ liter $\left.^{-1}\right)$ harmincszorosára $\left(\mathrm{OD}_{600} 0,19\right)$ hígítottuk, az atrazinkoncentráció $135 \mu \mathrm{M}$ volt. A plazmidok a következö géneket hordozták: pFAJ2350 (thcB); pFAJ2308 (thcBCD+orf5), pFAJ2309 (thcBCD)

\section{A $R$. erythropolis NI86/21 törzs atrazinbontó enzimei}

$\mathrm{Az}$ atrazinon tenyésztett NI86/21 törzsből izolált fehérjemintát kétdimenziós proteom analízissel elemeztük, és megállapítottuk, hogy a ThcA, ThcB, és ThcE proteinek nagy mennyiségben termelődtek, csakúgy, mint az EPTC-én tenyésztett sejtekben, viszont a ThcF nem termelődött (1D. ábra). Megvizsgáltuk az EPTC-t nem bontó mutáns törzs (FAJ2027) atrazinlebontó képességét is és azt találtuk, hogy az SQ1 törzshöz hasonlóan ez sem képes az atrazin bontására. Az EPTC-bontásért felelős thcB, thc $C$, és thcD gének bejuttatása ugyanakkor alkalmassá tette mindkét törzset az atrazin degradációjára, de a transzformált SQ1 törzs esetében ez a folyamat sokkal lassabb volt (2. táblázat II., III és IV. sorok) (NAGY et al., 1995a). E kísérletsorozat eredményeivel bizonyítottuk, hogy mind a tiokarbamátok, mind az atrazin lebontásáért (a thcF kivételével) ugyanazok a gének felelősek.

Eddigi ismereteink alapján a tiokarbamátok lebontását főleg Rhodococcus fajok katalizálják, a triazinok lebontására viszont mikrobiális közösségek és tiszta kultúrák is képesek. Jellemző, hogy a tiokarbamát-bontó Rhodococcus fajok triazinokat is tudnak bontani, bár sok esetben a bontás csak részleges (DE SCHRIJVER \& DE MOT, 1999). Az atrazin lebontásában a két leghatékonyabb mikrobának a Pseudomonas sp. és a Ralstonia brasilensis M91-3 bizonyult, mely baktériumok a molekulát teljesen mineralizálják (MANDELBAUM et al., 1995; STAMPER et al., 2002). Ennek ellenére a hosszú távú bioremediációs kísérletekben a $R$. erythropolis NI86/21 törzset kezdték el vizsgálni (VANCOV et al., 2005), mert a törzsnek olyan hasznos tulajdonságai vannak (pl. ellenálló sejtfal, túlélés extrém környezeti feltételek mellett), melyek sokkal előnyösebbé teszik alkalmazását. Kísérleteikben új módon kapszulázott NI86/21 sejteket hasz- 
náltak, és bebizonyitották, hogy az élő sejtek lassan, folyamatosan, hosszú időn keresztül szabadulnak ki a talajba vagy a felszíni vizekbe és ezáltal képesek a kis mennyiségben jelen lévő gyomirtószer-maradványokat is lebontani. Ennek eredményeként az atrazin nemkívánatos környezeti hatásai - melyek engedélyeztetését veszélyeztetik - a minimumra csökkenthetők.

\section{Összefoglalás}

A Rhodococcus fajok változatos metabolikus képességeik, robosztus sejtfelépítésük, és hidegtürésük révén meghatarozó környezetvédelmi, ipari és biotechnológiai objektumokká kezdenek válni. Kiemelkedő szerepük van az aromás szénhidrogének, klórozott fenolok, szterolok, peszticidek, valamint a lignin, a kőszén, és a nyersolaj atalakításában, lebontásában. E különleges szubsztrátok átalakításában az oxigenáz (CYP450), dioxigenáz, dehidrogenáz, hidroxiláz, hidroláz, dehalogenáz stb. enzimek nagy mennyiségben és variációban történő elöfordulása játszik lényegi szerepet, de nem elhanyagolható a rodokokkuszok rendkívüli oldószer-toleranciája, és az egy sejten belül megsokszorozódott gének ko-regulációjának, és néhány természetes emulgeátor szintezisének a képessége sem.

Jelen közleményben a $R$. erythropolis NI86/21 talajbaktérium mezőgazdasági biotechnológia/mikrobiológia tárgyú kutatásainkat foglaltam össze. Ezek közül három téma mutatkozik a gyakorlatban is hasznosíthatónak. A bioantidótum és az ehhez rokon fitoremediációs eljárások a peszticidek és az ipari szennyező anyagok által okozott környezeti terhelést csökkentik. A másik igéretes terület a $R$. erythropolis NI86/21 thcF génjével transzformált Arabidopsis thaliana növényben termelt természetes fungicid tanulmányozása, mely azt hivatott eldönteni, hogy e (máig azonosítatlan) vegyületnek van-e létjogosultsága a mezőgazdasági gyakorlatban. A harmadik, inkább ipari/bioremediációs jellegü kutatási irány a rodokokkuszok kapszulázása és felhasználása olyan szennyezett talajok és felszini vizek tisztítására, ahol a szennyező anyagok kis koncentrációban, de folyamatosan kerülnek a környezetbe, és ennek megfelelően arra van szükség, hogy a rodokokkusz sejtek állandóan jelen legyenek a biotópban.

\section{Irodalom}

ANKumah, R. O. et al., 1995. Metabolism of carbamothioate herbicide, EPTC, by Rhodococcus strain JE1 isolated from soil. Soil Sci. Soc. Am. J. 59. 1071-1077.

BehKi, R. M. \& Khan, S. U., 1990. Degradation ff [1-C-14-propyl]EPTC (S-ethyl dipropylthiocarbamate) by a soil bacterial isolate. Chemosphere. 21. 1457-1463.

BeHKI, R. M. et al., 1993. Metabolism of the herbicide atrazine by Rhodococcus strains. Appl. Environ. Microbiol. 59. 1955-1959.

Biró, B. \& KeCSKÉS, M., 1984. Herbicide sensitivity of Coronilla Rhizobium and Pseudomonas rhizobacterium strains. Acta Microbiol. Hung. 31. 302-303.

DE Mot, R. et al., 2003. The thiocarbamate-inducible Rhodococcus enzyme ThcF as a member of the family of alpha/beta hydrolases with haloperoxidative side activity. FEMS Microbiol. Lett. 224. 197-203.

De Schrijver, A. \& De Mot, R., 1999. Degradation of pesticides by actinomycetes. Crit. Rev. Microbiol. 25. 85-119. 
De SCHRIJVER, A. et al., 1997. Thiocarbamate herbicide-inducible nonheme haloperoxidase of Rhodococcus erythropolis NI86/21. Appl. Environ. Microbiol. 63. 1911-1916.

GRAY, R. A. \& WEIERICH, A. J., 1968. Behavior and persistance of thiocarbamate herbicides in soils under different environmental conditions. Proc. $9^{\text {th }}$ Brit. Weed Control Conference. 94 101. British Crop Production Council. Brighton.

JACKS, T. J. et al., 2000. Antifungal and peroxidative activities of nonheme chloroperoxidase in relation to transgenic plant protection. J. Agric. Food Chem. 48. 4561-4564.

KÁtAI, J., 1997. The effect of herbicides on the abundance and activity of microbes in the soil. In: Soil Pollution. (Ed.: FILEP, Gy.) 159-167. Rexpo Ltd. Debrecen.

KECSKÉS M., 1976. Mikroorganizmusok, magasabbrendü növények és xenobiotikumok közötti kölcsönhatások értékelése. Akadémiai doktori értekezés és tézisei. Budapest.

KwON, Y. D. et al., 2004. Crystal structures of the Rhodococcus proteasome with and without its pro-peptides: Implications for the role of the pro-peptide in proteasome assembly. J. Mol. Biol. 335. 233-245.

MANDElbaum, R. T. et al., 1995. Isolation and characterization of a Pseudomonas sp. that mineralizes the S-triazine herbicide atrazine. Appl. Environ. Microbiol. 61. 1451-1457.

MitANI, Y. et al., 2006. Gene expression analysis using a modified HiCEP method applicable to prokaryotes: A study of the response of Rhodococcus to isoniazid and ethambutol. J. Biotechnol. 123. 259-272.

NAGY I., 1989. Extenderek, tiokarbamát herbicidek, mikroorganizmusok és növények közötti kölcsönhatások. Kandidátusi értekezés. Gödöllöi Agrártudományi Egyetem. Gödöllő.

NAGY, I. et al., 1987a. Decomposition of EPTC by soil microbes in two soils. In: Proc. British Plant Protection Conference, Brighton - Weeds. I. 525-530. Lavenham Press Ltd. Lavenham, UK.

NAGY, I. et al., 1987b. Process for preparation and use of antidote carrying micro- and macroorganisms, useful for covering the cultivated plant-damaging effect of thiocarbamates and chloroacetanilides. North Hungarian Chemical Works. Hungarian Patent 202058.

NAGY, I. et al., 1995a. A single cytochrome-P-450 system is involved in degradation of the herbicides EPTC (S-ethyl dipropylthiocarbamate) and atrazine by Rhodococcus sp. strain NI86/21. Appl. Environ. Microbiol. 61. 2056-2060.

NAGY, I. et al., 1995b. Degradation of the thiocarbamate herbicide EPTC (S-ethyl dipropylcarbamothioate) and biosafening by Rhodococcus sp. strain NI86/21 involve an inducible cytochrome-P-450 system and aldehyde dehydrogenase. J. Bacteriol. 177. 676-687.

NAGY, I. et al., 1995c. Characterization of the Rhodococcus sp. NI86/21 gene encoding alcohol N,N'-dimethyl-4-nitrosoaniline oxidoreductase inducible by atrazine and thiocarbamate herbicides. Arch. Microbiol. 163. 439-446.

OBRigawitch, T. et al., 1982. The influence of temperature, moisture, and prior EPTC application on the degradation of EPTC in soils. Weed Science. 30. 175-181.

Parsot, C. \& Mekalanos, J. J., 1991. Expression of the Vibrio cholerae gene encoding aldehyde dehydrogenase is under control of toxr, the cholera-toxin transcriptional activator. J. Bacteriol. 173. 2842-2851.

Phillips, M. \& McDougall, J., 1993. Carbamate herbicides. In: Wood-McKenzie Report. Part 1. Wood Mackenzie Consultants Ltd. Edinburgh.

PRIEFERT, H. et al., 1992. Identification and molecular characterization of the gene coding for acetaldehyde dehydrogenase-Ii (Acod) of Alcaligenes eutrophus. J. Bacteriol. 174. 899-907.

RAhman, A. et al., 1979. Eradicane causes problems. New Zealand Journal of Agriculture 139. $47-49$.

SELS, J., 2003. Studie van de activiteit in Arabidopsis thaliana planten getransformeerd met een bacterieel esterase-gen, Katholieke Universiteit Leuven. Belgium.

STAMPER, D. M. et al., 2002. Ralstonia basilensis M91-3, a denitrifying soil bacterium capable of using S-triazines as nitrogen sources. Can. J. Microbiol. 48. 1089-1098. 
TAMURA, T. et al., 1995. The first characterization of a eubacterial proteasome - the 20S complex of Rhodococcus. Curr. Biol. 5. 766-774.

VANCOV, T. et al., 2005. Atrazine degradation by encapsulated Rhodococcus erythropolis NI86/21. J. Appl. Microbiol. 99. 767-775.

Velghe, I., 2004. Karakterisatie van de antifungale componenten uit Arabidopsis thalianaplanten getransformeerd met een bacterieel esterase-gen, Katolieke Universiteit. Leuven.

Ware, G. W., 1994. The Pesticide Book. $4^{\text {th }}$ ed. Thomaspublications. California.

WolfFramm, C. et al., 1993. Chloroperoxidase encoding gene from Pseudomonas pyrrocinia Sequence, expression in heterologous hosts, and purification of the enzyme. Gene. 130. 131135.

ZUHL, F. et al., 1997. Subunit topology of the Rhodococcus proteasome. FEBS Lett. 400. 83-90.

Érkezett: 2006. szeptember 6.

NAGY ISTVÁN

Max-Planck Biokémiai Intézet, Martinsried Németország

Postai cím: NAGY ISTVÁN, Max-Planck-Inst. für Biochemie Abt. Molekulare Strukturbiologie, D-82152 Martinsried, Am Klopferspitz 18, Deutschland. E-mail: nagy@biochem.mpg.de 